\title{
VI SPOTKANIE STOWARZYSZENIA KOORDYNATORÓW KATOLICKICH SZKÓK EWANGELIZACJI W MEDIOLANIE (1994)
}

W dniach 13-17 IV 1994 r. odbyło się coroczne spotkanie koordynatorów katolickich szkół ewangelizacji (ACCSE/2000 - Association of Coordinators of Catholic Schools of Evangelization) w parafii S. Eustorgio w Mediolanie, gdzie w małych grupach dzielenia, tzw. komórkach parafialnych, spotyka się ponad 1000 wiernych. W spotkaniu wzięło udział 62 delegatów z 38 szkół ewangelizacji z 17 krajów Europy. Gospodarzem spotkania był proboszcz bazyliki, ks. Pigi Perini, który zapoczątkował ewangelizacyjny system komórek parafialnych w $1988 \mathrm{r}$. Obecnie istnieje 70 komórek, w których parafianie spotykają się na modlitwie, dzieleniu i czytaniu Pisma świętego, raz w tygodniu przez dwie godziny. Spotkania w domach parafian są prowadzone przez przygotowanych animatorów.

Tematem tegorocznego spotkania ACCSE/2000 byly slowa z Mt 28,19; „Czyńcie uczniów ze wszystkich narodów”. Pierwszą konferencję Koszt bycia uczniem, która stanowiła przedmiot refleksji i dzielenia pierwszego dnia, wygłosił ks. Jim Bermingham, dyrektor ACCSE/2000 Africa. Podkreślił on, że bycie uczniem Chrystusa jest przede wszystkim odpowiedzią na Jego powołanie: „Chodź i zobacz”, odpowiedzią na wezwanie Jana Pawła II do nowej ewangelizacji i odpowiedzią na potrzeby współczesnego Kościoła. Cechą ucznia jest: przemiana w Chrystusie (Mk 8,34-38), oddanie Bogu całego serca, zostawienie swoich dóbr, poddanie woli (Mt 10,34), czynienie uczniów. Koszt bycia uczniem Jezusa Chrystusa jest bardzo duży, największą ceną przez przemianę mentalności - metanoia. Po konferencji było dzielenie się w grupach, co to znaczy być uczniem i jaki koszt się z tym wiąże. Ważnym momentem tego dnia było uczestnictwo w spotkaniu komórek parafialnych, które poprzedziło wyjaśnienie systemu komórek parafialnych oraz adoracja Najświętszego Sakramentu.

W drugim dniu tematem rozważań było czynienie uczniów i metody ewangelizacji. Poszczególne referaty przedstawiali dyrektorzy parafialnych i stacjonarnych szkół ewangelizacji. Mówili między innymi o treści orędzia ewangelizacyjnego, metodach skutecznej ewangelizacji, postawach ewangelizatora i niebezpieczeństwach, jakie niosą różne środki i metody ewangelizacji. W południe uczestników spotkania przyjął kard. Carlo Maria Martini, który podkreślił, że ewangelizacja należy do całego Kościoła, do każdego wierzącego, dlaczego zatem, zapytał, istnieje potrzeba szkół ewangelizacji dla czegoś, co winno być zasađniczą cechą każdego chrześcijanina. W krótkim słowie do koordynatorów wspomniał o potrzebie ewangelizującego Kościoła, potrzebie rozeznania, jak dzieje apostolskie są pisane w obecnym świecie.

Tematem trzeciego dnia bylo: Czynienie uczniów a metodologie szkót. Głównym celem wystąpień było przedstawienie metodologii różnych szkół: kerygmatycznej szkoły Wspólnoty Jana Chrzciciela z Camparmo, Włochy; Centrum Ewangelizacji z Mainhingen, Niemcy; Wspólnoty Życia i Kontemplacji z Chemin Neuf, Francja; Międzynarodowego Centrum Ewangelizacji na Malcie; Instytutu Katechetycznego z Suwałk, prowadzącego zajęcia na Litwie i Białorusi oraz Parafialnej Szkoły Katechumenatu z Tomska, Syberia. Wieczorem była liturgia pojednania i sakrament pokuty. 
W ostatnim dniu, niedzieli, tematem była Ewangelizacja przez liturgię, a punktem centralnym uczestnictwo w niedzielnej Eucharystii w bazylice S. Eustorgio. Msza św. sprawowana była według obrządku ambrozjańskiego i trwała ponad dwie godziny. Pół godziny przed Mszą św. 50 animatorów komórek parafialnych modliło się z księdzem proboszczem w zakrystii $w$ intencji tej liturgii i parafii. W liturgii, pod przewodnictwem ks. proboszcza, ponad 30 świeckich pełnilo 26 różnych posług, średnia wieku ministrantów - 40 lat. Wszystkie części liturgii podkreślały wspólnotowy wymiar Kościoła: uroczyste powitanie wszystkich, którzy pierwszy raz przyszli do tego kościoła, przedstawienie kapłanów sprawujących Eucharystię, komentarze do czytań biblijnych, znak pokoju po liturgii słowa, przyniesienie darów: kolekty pieniężnej i kosztów z żywnością i ubraniami dla misji na Filipinach, procesja komunijna, w której wierni podchodzili trzymając rękę na ramieniu drugiej osoby, Komunia pod dwiema postaciami i rozmowy kapłanów $z$ wiernymi przed kościolem po zakończeniu Eucharystii. Należy podkreślić, że była to normalna Msza niedzielna w parafii, pełna dynamicznej wiary i modlitwy.

Kraków

MARIA KANTOR

\section{Ks. Jerzy Chmiel}

\section{KRONIKA BIBLIJNA (1)}

\section{KONKURS WIEDZY BIBLIJNEJ KATOLICKICH SZKOE SREDNICH - KRAKOW' 94}

Katolickie Liceum Ogólnokształcące Księży Pijarów w Krakowie zorganizowało dla katolickich szkół średnich w Polsce konkurs wiedzy biblijnej. Na zaproszenie odpowiedziało wiele szkół licealnych z całej Polski, w sumie stanęlo do konkursu 52 uczniów i uczennic. Uczestnicy przyjechali do Krakowa w piątek, 25. lutego 1994 r. i zamieszkali w internacie Liceum pijarskiego przy ul. Akacjowej (Kliny). Następnego dnia, w sobotę, 26. lutego, Mszą świętą koncelebrowaną pod przewodnictwem ks. Jerzego Chmiela z PAT, który też wygłosił homilię, rozpoczęli konkurs w budynku Liceum. Jury konkursowemu przewodniczył ks. Chmiel.

Konkurs składał się $\mathrm{z}$ trzech rund odpowiednio przygotowanych pytań, na które trzeba było odpowiedzieć najpierw pisemnie, a potem ustnie. Pytania obejmowały Pięcioksiąg i Ewangelie. Poziom przygotowania uczestników był bardzo dobry. Wyłoniono troje zwycięzców, którzy otrzymali nagrody ufundowane przez Zarząd Polskiej Prowincji Szkół Pobożnych, z racji jubileuszu pijarów w Polsce, ale byli też i prywatni sponsorzy. Tymi nagrodami był udział w wycieczce do Hiszpanii i Portugalii.

Uczestnicy konkursu spoza Krakowa mieli możność obejrzenia miasta i udziału w jakimś spektaklu artystycznym (teatr, filharmonia). Był to pierwszy na skalę ogólnopolską urządzony konkurs biblijny młodzieży szkół licealnych od II wojny światowej, a prawdopodobnie - jako konkurs wyłącznie wiedzy biblijnej - pierwszy w Polsce. Zostawił bardzo dobre wrażenie - dlatego vivant sequentes! 